\title{
Analysis of the Oxidative Stress Parameters in Testicular, Hepatic and Renal Tissues Homogenates of Albino Rats after Administration of Imatinib at Peripuberty
}

\author{
*Luma I. Al-Allaf \\ Hafidh Al-Ashoo \\ Department of Anatomy/ College of Medicine/ University of Mosul \\ *E-mail: lumaallaf1971@yahoo.com
}

(Received 23/9/2018; Accepted 1/11/2018)

\begin{abstract}
Background: Targeted small molecule drugs have revolutionized treatment of chronic myelogenous leukemia (CML) over the last two decades. The safety zone of imatinib, and specifically its relevancy to organ toxicity, has been discussed in a controversial manner in current years. There is a little data on the contribution of oxidative stress in imatinib induced organ toxicities

Objectives: This work aims to analyze the possible role of oxidative stress in the occurrence of testicular, hepatic and renal toxicities induced by imatinib (if present) by analyzing some parameters including glutathione (GSH), malondialdehyde (MDA) levels in their homogenates.

Study setting and design: This experimental study was conducted on male Albino rats (purchased from Animal Houses of both Mosul Medical College, and Veterinary College, University of Mosul, Mosul, Northern Iraq).

Methods: This work included 40- 45 days aged rats (at peripuberty) (n=8) which administered a single daily dose of $200 \mathrm{mg} / \mathrm{kg}$ of imatinib mesylate for 30 days (100mg capsule, Glivec ${ }^{\circledR}$, STI 571; Novartis) bought from Ibn-Sena Teaching Hospital, Mosul, Northern Iraq, or bought from some private pharmacies and were dissolved in distilled water (D.W) and given orally by gavage with 24 gage needle. Another group of 8 rats were administered with D.W represents an age matched control. Testes, livers, parts and kidneys were collected from all rats. Tissue GSH, MDA concentrations in the homogenates of the three organs were determined by spectrophotometer according to the methods described.

Results: All rats survived the experimental period. This study revealed a decrease in value of GSH in the testicular and hepatic tissues of the treated rats, however, the concentrations of this antioxidant in renal tissue were higher than that of control ones. Briefly, imatinib induced an elevation of MDA productions in both testicular and hepatic tissues when compared to the control group. MDA concentrations in renal homogenates in the treated group were lower than that of control ones.

Conclusion: Imatinib induced a decrease in the level of GSH and increased in level of MDA in testicular, hepatic homogenates indicating its oxidative effect.
\end{abstract}

Keywords: Imatinib mesylate, albino rats, glutathione, malondialdehyde.

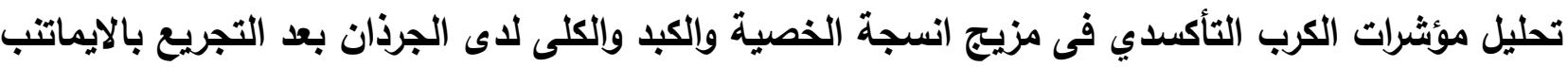

$$
\begin{aligned}
& \text { الملخص } \\
& \text { الخلقيـة: ان الأدويـة المسـتهدفة للجزيئـات الصـغيرة قد احدثت ثورة فـى عـلاج مـرض ابيضـاض الـدم المـزمن خـلال العقدين } \\
& \text { المنصرمين. ان المنطقة الامنة للايماتتب وخصوصا علاقته مع سمية الاعضاء قد نوقتت بطريقة متناقضة فى السنوات الحالية. } \\
& \text { هناك بيانات قليلة عن مساهمة الكرب التاكسدى في سمية الأعضاء الناتجة عن الايماتتب. }
\end{aligned}
$$




\section{أهداف الدراسة: يهدف هذا العمل الى تحليل الدور الاحتمالي للكرب التاكسدى فى حدوث سمية الخصية والكبد والكلى الناتجة عن الايمانتب (اذا ما كانت موجودة) وذللك عن طريق تحليل بعض المؤشرات التي تتمل مستويات الكلوناثايون المالوندالديهايد في مزيج أنسجة تلاك الأعضاء. مكان الدراسة: هذه الدراسة التجريبية اجريت على الجرذان المهقاء والمهاة من بيتي الحيوانات التابعين لكليتي طب الموصل والطب البيطرى، جامعة الموصل فى مدينة الموصل شمالي العراق. طرائق العمل: تضمن العمل تجريع الجرذان بعمر 40-45 يوما (حول البلوغ) وعددهم ثمانية وذلك عن طريق الفئ الفم يوميا بمقدار 200 ملغرام لكل كيلوغرام من وزن الجسم ولمدة شهر بعقار الايماتتب مسيليت (كليفك، نوفارتس) مهداة من مستشفى ابن سينا

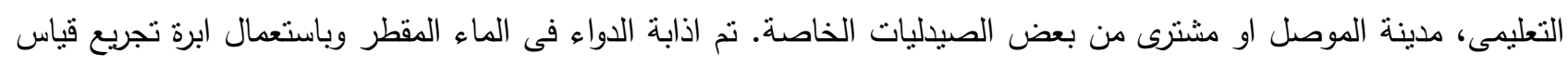

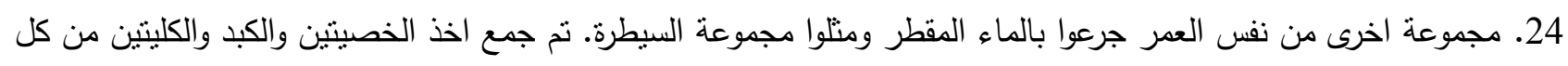

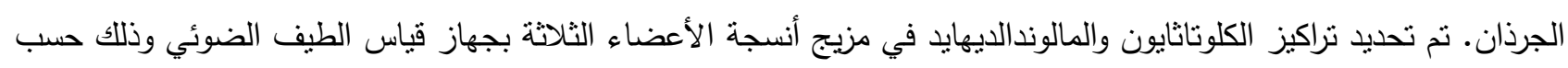 الطرق المعتمدة. النتائج: كل الجرذان عاشوا خلال طول فترة التجربة. هذه الدراسة أوضحت ان هناك قلة فى مستوى الكلوتاثايون في نسيج الخصية والكبد فى الجرذان المعاملة مع العلم ان مسنوى هذا المضاد التاكسدى في نسيج الكلى قد كان اعلى من مجموعة السيطرة. بطريقة

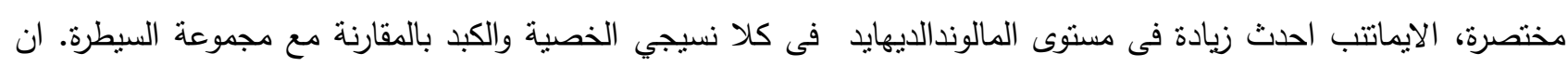 مستوى المالونداليهايد فى نسيج الكلى فى مجموعة المعاملة كان اقل من ذلك العائد لمجموعة السيطرة. الاستتتاجات: ان الايماتتب قد سبب انخفاضا فى مستوى الكلوناثايون وزيادة في مستوى المالوندالديهايد في مزيجي الخصية والكبد مما يدل على تأثيره الاوكسيدى. الكلمات الدالة: الايماتتب ميسيليت، الجرذان المهقاء، الكلوتاثايون، المالوندالديهايد.}

\section{INTRODUCTION}

Cancer is the second most dominant cause of death in the world. Although cancer commonly affects people after they have completed their families, a serious minority are diagnosed at a younger age (Howell and Shalet, 2005).

These patients have to suffer not only with the effect of having cancer and the immediate complications of treatment, but also with the possibility that chemotherapy may lead to temporary or permanent sequalae as gonadal damage, infertility, and organs toxicity (Mohan and Bhandare, 2012; Ramos et al., 2013).

Tyrosine kinase inhibitors (TKIs) are a relatively recent class of anticancer agents that target cellular pathways over expressed in special types of tumors (Sawyers, 2003; Herman et al., 2011; Shah et al., 2013).

The safety zone of imatinib, and specifically its relevancy to organ toxicity, has been discussed in a controversial manner in current years (Thanopoulou and Judson, 2012; Wolf et al., 2010).

There is a report of the gastrointestinal stromal tumors (GIST) patient or CML patient with male gynaecomastia and testicular hydrocele after exposure to imatinib mesylate(Kim et al.,2005). Several researches have investigated the possible mechanism of imatinib-causing organ toxicity and it has been suggested that the effect is attributed to various mechanisms (Kerkela" et al., 2006; Ribeiro et al., 2008).

Interestingly, imatinib also showed adverse toxic action on cultivated cardiomyocytes, mostly due to a generation of endoplasmic reticulum (ER) stress, leading to diminished translation, an arrest in protein synthesis and oxidative stress (Kerkela“ et al., 2006). 
Over the last fifteen years, there has been a developing concept that reactive oxygen species (ROS) production has a vital role in a wide spectrum of cellular processes, ROS are heterogeneously a group of molecules and free radicals as a derivative product from diatomic oxygen, with a non-specialized range of reactivity (Finkel, 2003).

In fact, it has been suggested that oxidative stress has a role in imatinib - induced organs toxicity (Cheng and Force, 2010); Prasad et al., 2010). Moreover, it has been speculated that activation of ER stress after imatinib therapy is one of the causes of imatinib -mediated toxicity (Han et al., 2009; $\underline{\mathrm{Hu}}$ et al., 2012).

For many years chemists have known that free radicals lead to oxidation which can be under control or blocked by a range of antioxidants substances (Bjelakovic et al., 2007).

There are several markers for oxidative stress including reduced glutathione (GSH), and malondialdehyde (MDA) (Saad et al., 2006; Kose et al., 2012).

The reduced glutathione is a crucial radical located inside cells that react with free radicals in direct or indirect manner and contributes in processes of detoxification, while MDA is an organic substance that produced in oxidative stress (Murawska-Ciałowicz et al., 2012). Both of these markers are utilized to measure the level of oxidative stress in scientific researches.

There is a little data on the contribution of oxidative stress in imatinib induced organ toxicities. The aim of the present work is to analyze the possible role of oxidative stress in the occurrence of testicular, hepatic and renal toxicities induced by imatinib (if present) by analyzing some parameters including GSH and MDA levels in their homogenates in male albino rats.

\section{MATERIALS AND METHODS}

This experimental study was conducted on male Albino rats (purchased from Animal Houses of both Mosul Medical College, and Veterinary College, university of Mosul, Mosul, Northern Iraq). The study performed at department of Anatomy, Mosul Medical College, University of Mosul, Mosul, Northern Iraq.

During the investigations the rats were placed under well-controlled normal environmental and laboratory situations and animal facility and were looked after in an air-conditioned room with twelve -hours light and dark cycles, where the temperature $\left(23 \pm 2{ }^{\circ} \mathrm{C}\right)$ and relative humidity $(68-70 \%)$ were kept stable. They were bred nearby and put separately in Animal House plastic cages (North Kent, England) measuring $47 \times 34 \times 18 \mathrm{~cm}$ filled from inside with wood chips (Favareto et al., 2011). Animals were allowed to acclimatize for seven days prior to any experiment was performed (Ilbey et al., 2009) and supplied with free access of water ad libitum and packed optimized food (commercial rodent chow) (D‘Souza UJA, 2003). All rats were provided with humane care, and procedures enrolling animals and their care were performed with conformation with universal laws and policies and the studies on animals approved. The experiments were performed during the light part (Mohan and Bhandare, 2012).

\section{Experimental Design and Procedures}

Animals were randomly selected and labeled to the experimental groups. This work included 40- 45 days aged rats (at peripuberty) $(\mathrm{n}=8)$ which administered a single daily dose of $200 \mathrm{mg} / \mathrm{kg}$ of imatinib mesylate for 30 days (100mg capsule, Glivec ${ }^{\circledR}$, STI 571; Novartis, Basel, Switzerland) bought from Ibn-Sena Teaching Hospital, Mosul, Northern Iraq, or bought from some private pharmacies and were dissolved in distilled water and given orally by gavage with 24 gage needle at Animal House of Mosul Medical College in order to adjust the doses which will be chosen in the study to be in the safe range of the dose (Yaghmaei et al., 2009). The rats were properly restrained (the rats were held by the loose skin of their neck and back) to stabilize the head and kept in an upright (vertical) position. The gavage needle was appropriately fixed on Mantoux syringe and was introduced through the side of the mouth, observed the roof of the mouth, and passed into the esophagus toward the stomach. After the needle was passed to the proper length, imatinib was injected (Nurmio et al., 2007). 
Imatinib dose were chosen as the range of those applied in clinical treatment protocols (Kerkela“" et al., 2006) which is $\left(400-800 \mathrm{mg} / \mathrm{d}\right.$ or $340-590 \mathrm{mg} / \mathrm{m}^{2}$ based on a weight of $70 \mathrm{~kg}$ ) dose surface area modified to body-weight, via the formula:

$f \times \mathrm{mg} / \mathrm{kg}=\mathrm{mg} / \mathrm{m}^{2}$, where $f$ is a stable value equal to 6.0 in rats (Bachmann et al., 1996).

Each treated animal was monitored for unconcealed signs of toxicity for the next four hours, and mortality throughout the next 24 hours.

Another group of 8 rats were administered with distilled water represents an age matched control. Animals were euthanized with ether (Merck, Germany) (Favareto et al., 2011) after 24 hours of last day of treatment at the laboratory of postgraduate studies of Department of Anatomy, Mosul College of Medicine.

Testes, livers, parts and kidneys were collected from rats of all rats in a careful way during laparatomy with infectious precautions (Al-Allaf and Al-Ashoo, 2014) and they were immediately weighed and examined macroscopically before they were immersed in $\mathrm{NaCl}$ solution $0.9 \%$ for few seconds in order to get rid of superficial blood.

\section{Analysis for Parameters of Oxidative Stress}

Fresh specimens $(0.5 \mathrm{gm})$ from each rat's testes, liver, and kidneys of rats were obtained and frozen. Then at time of procedure for biochemical analysis each specimen thawed individually and washed using cold saline. Then after blotting with a filter paper, it was weighed, and de-capsulated. Tissue homogenization was performed manually and centrifuging was done (Hettich EBA 20, Germany) at 4000 round per minute(RPM) for 10 minutes. Tissue GSH, MDA concentrations in the homogenates were determined using spectrophotometer according to the methods described (Sedlak and Lindsay, 1968; Guidet and Shah, 1989).

Statistical Analysis

Data were recorded using excel program and the data analyzed using Microsoft Statistical Package Social Statistics (SPSS) software (version 17). Chi-square test was performed for comparing means of different values in the study groups. Value was considered as significant when it was <0.05 (Armitage et al., 2002).

\section{RESULTS}

All rats survived the experimental period. This study revealed a decrease in value of GSH in the testicular and hepatic tissues of the treated rats, however, the concentrations of this antioxidant in renal tissue were higher than that of control ones Fig. (1).

The summary of the impact of imatinib treatment on the levels of GSH and MDA in rats' homogenates is shown in (Table 1).

Briefly, imatinib induced an elevation of MDA productions in both testicular and hepatic tissues when compared to the control group Fig. (2). MDA concentrations in renal homogenates in the treated group were lower than that of control ones.

Table 1: Comparison between GSH and MDA concentrations in testicular, hepatic and renal homogenates of control and treated rats.

\begin{tabular}{|c|c|c|c|c|c|c|c|}
\hline \multicolumn{2}{|c|}{$\begin{array}{c}\text { Gontrol } \\
\text { N=8 } \\
\text { mean } \pm \text { SD }\end{array}$} & \multicolumn{3}{c|}{$\begin{array}{c}\text { Imatinib } \\
\text { N=8 } \\
\text { mean } \pm \text { SD }\end{array}$} & P-Value \\
\cline { 2 - 8 } & Testes & Liver & Kidneys & Testes & Liver & Kidneys & \\
\hline Parameters & 14.9 & 56.5 & 34.5 & 3.8 & 13.4 & 71.1 & $\mathrm{P}<0.05$ \\
\hline $\mathrm{GSH}(\mu$ mol/g of the tissue $)$ & 18.7 & 1.93 & 22.5 & 30.75 & 3.97 & 2.8 & $\mathrm{P}<0.05$ \\
\hline MDA(n mol/g of the tissue) & & & & & & & \\
\hline
\end{tabular}


$* \mathrm{P}$-value is considered as significant when $<0.05$.

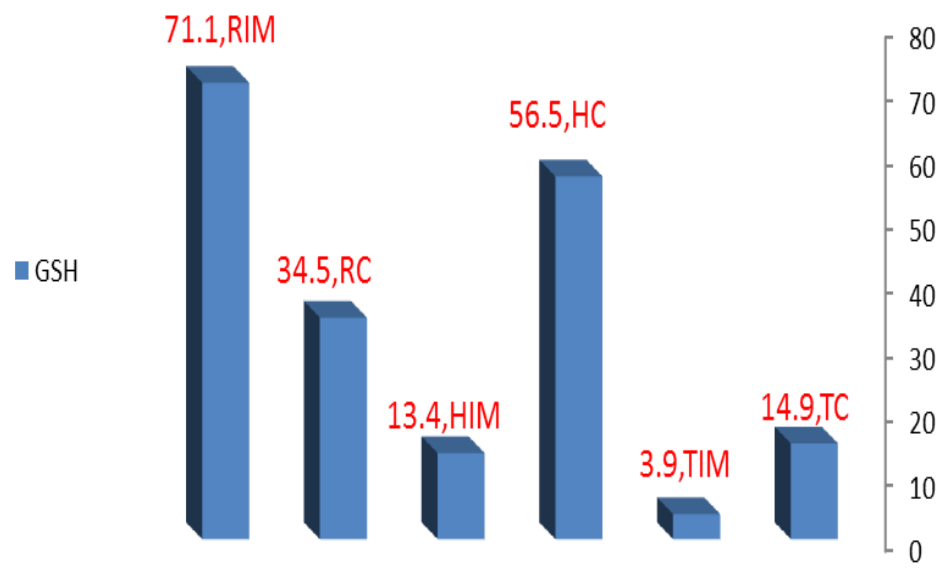

Fig. 1: A histogram shows the comparison of GSH concentrations in testicular, hepatic and renal homogenates of control and treated rats.

*TC, Mean concentration in testicular tissue of control group; TIM, Mean concentration in testicular tissue of imatinib group; HC, Mean concentration in hepatic tissue of control group; HIM, Mean concentration in hepatic tissue of imatinib group; RC, Mean concentration in renal tissue of control group; RIM Mean concentration in the renal tissue of imatinib group.

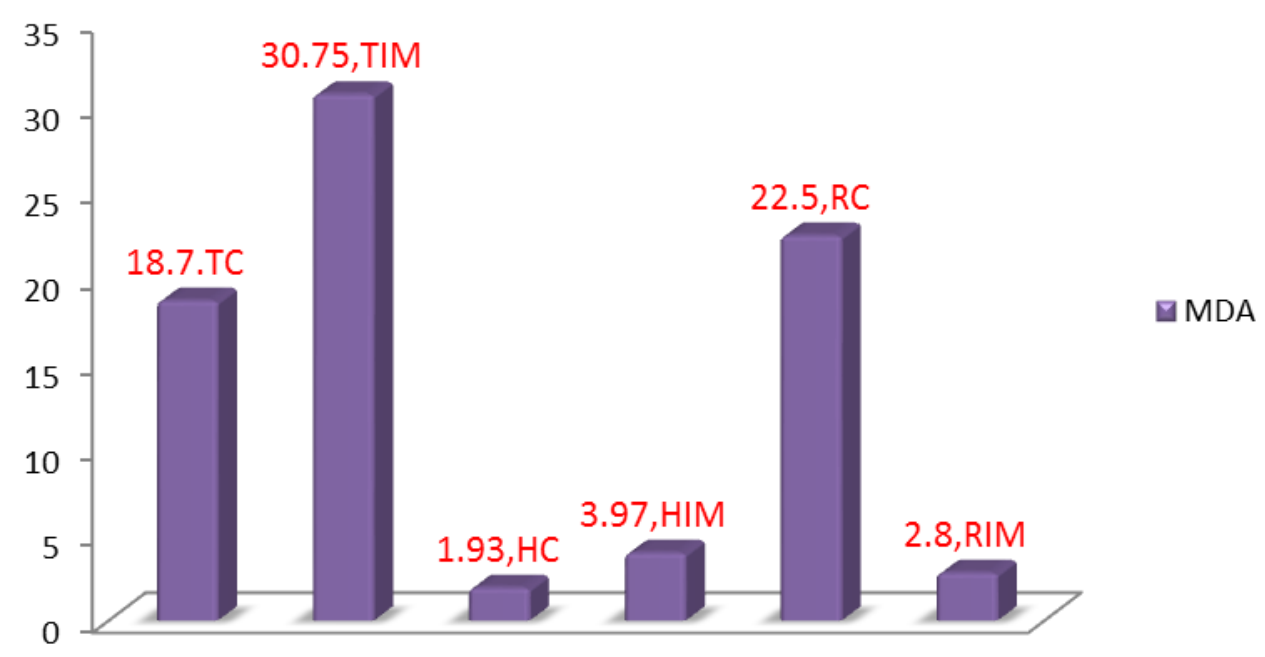

Fig. 2: A histogram shows the comparison of MDA concentrations in testicular ,hepatic and renal homogenates of control and treated rats.

*TC, Mean concentration in testicular tissue of control group; TIM, Mean concentration in testicular tissue of imatinib group; HC, Mean concentration in hepatic tissue of control group; HIM, Mean concentration in hepatic tissue of imatinib group; RC, Mean concentration in renal tissue of control group; RIM Mean concentration in the renal tissue of imatinib group.

\section{DISCUSSION}

Little data is available on the influence of imatinib on internal organs such as testes, liver and kidneys and the possible underlying mechanisms of their toxicities if present remain unclear. 
It has been reported that imatinib apoptosis in the seminiferous epithelium which is due to several stimuli for examples: DNA damage, activation of apoptotic genes, and oxidative stress (Favareto et al., 2011; Kim et al., 2002).

Perivascular fibrosis and hyalinization of intertubular connective tissue were observed in sections of imatinib treated rats (Ceribasi et al., 2010). They reported that the damage noticed in the histological structure of the testis may clarify the direct and indirect effect of cytotoxics, which later enhance lipid peroxidation that is a chemical mechanism responsible for both structural and functional disruption of testis. It has been suggested that oxidative stress is known to stimulate various transcription factors which may cause an over nitric oxide generation and that results vasodilatation, and functional impairment of organs (Favareto et al., 2011).

On the other hand, Imatinib-is suggested to play a role in oxidative stress via activation of ER stress (Herman et al., 2011; Han et al., 2009), changes in the MMP and induction of apoptosis (Lubgan et al., 2006), and blocking of PDGF receptor and c-Ab1 gene (Saad et al., 2006). Any pathological state that provokes the over production and/or ineffective scavenging of ROS may play a critical role in inducing tissue injury (Aitken and Roman, 2009). It has been considered that hydropic degeneration of hepatocytes (as noticed in sections of rats treated with imatinib) may be attributed to the oxidative stress as it is associated with NO generation (Kose et al., 2012). They reported that this lesion represents the beginning of irreversible damage associated with methotraxate administration and reflects its oxidative effect.

The mechanism of glomerular and tubular injury such as swelling of their lining epithelial cells starts as a depletion in $\mathrm{O} 2$ levels which lead to a drop in aerobic respiration. Renal cells consume oxygen at a high rate and are highly dependent on aerobic metabolism for ATP generation the cells must depend more on glycolysis. Glycolysis leads to lactic acid increasing (Vickers et al., 2004). Prolonged ischemia can lead to mitochondrial and lysosomal, and membrane damages (Cui et al., 2013).

In the present investigation, many renal tubules of the rat kidneys showed marked degenerative lesions under the effect of imatinib. This is justifiable as the renal tubules are especially susceptible to toxic influences, in part because they have high oxygen consumption and vulnerable enzyme systems (Cui et al., 2013). Also the tubules come in direct contact with toxic compounds during their excretion and elimination by the kidneys (Marcolino et al., 2011).

Such degenerative changes were markedly pronounced in the proximal convoluted tubules, these findings are similar to those of another study (Padmini and Kumar, 2013). In addition, disintegration of brush border membrane was shown in the present study, which may be responsible for the observed impairment of the renal function (Deveci et al., 2011), beside that ,this study revealed a decrease in mitochondraial contents in the proximal convoluted tubules which may be considered as a consequences of persistent ischemia (Cui et al., 2013).

To clarify the role of oxidative stress in imatinib induced cytotoxicity evaluation of oxidative stress parameters was performed in this work. Changes in GSH concentrations in rats' organs after exposure to imatinib were measured. It was observed that the concentrations of this antioxidant in the testicular and hepatic homogenates are decreased in the treated group. These findings are similar to those of others (Mohan and Bhandare, 2012; Shaker et al., 2011).

On the other hand, imatinib caused an increase in MDA levels. Malondialdehyde mediates the processes of lipid peroxidation which may contribute in the development of tissue damage (Kose et al., 2012).

Studies reported a significant increase in cardiac MDA production level and attributed that to imatinib- induced c-Ab1 and PDGF receptor inhibition, contributing to peroxidative-induced myocardial damage (Saad et al., 2006) or due to mitochondrial and ER related pathways as confirmed by the ultrastructural findings (Hassan and Yousif, 2013).

On contrary, this study revealed an increased level of GSH in renal homogenates which may be attributed to raised sensitivity of kidneys to activities of free radicals, and having of anti- 
oxidative potential or due to the compensatory mechanism as reflected by the decrease in the level of MDA in renal homogenates.

In conclusions: Imatinib induced biochemical changes (especially in testicular and hepatic tissues) indicating that oxidative stress plays a role in its toxic effects.

\section{REFERENCES}

Aitken, R.J.; Roman, S.D. (2009). Antioxidant systems and oxidative stress in the testes. Adv. Exp . Med. Biol., 636, 154-171.

Al-Allaf, L.I.K.; Al-Ashoo, H.A. (2014). The effects of imatinib on the testicular histology in male rats administered at peripubertal period. JABHS, 15(1), 24-34.

Armitage, P.; Berry, G.; Matthews, J.N.S. (2002). "Statistical Methods in Medical Research". $4^{\text {th }}$ ed., Blackwell, Oxford, UK, pp. 147-272.

Bjelakovic, G.; Nikolova, D.; Gluud, L.L. (2007). Mortality in randomized trials of antioxidant supplements for primary and secondary prevention: systematic review and meta-analysis. JAMA, 297(8), 842-857.

Ceribasi, A.O.; Turk, G.; Sçnmez, M. (2010). Toxic effect of cyclophosphamide on sperm morphology, testicular histology and blood oxidant-antioxidant balance, and protective roles of lycopene and ellagic acid. Bas and Clin Pharmacol. and Toxicol., 107, 730-736.

Cheng, H.; Force, T. (2010). Molecular mechanisms of cardiovascular toxicity of targeted cancer therapeutics. Circ Res, 106, 21-34.

Cui, J.; Shi, S.; Sun, X. (2013). Mitochondrial autophagy involving renal injury and aging is modulated by caloric intake in aged rat kidneys. PLOS ONE. 8(7), e69720. doi: 10.1371.

D‘Souza, U.J.A. (2003). Toxic effects of 5-fluorouracil on sperm count in wistar rats. Malays $J$. Med Sci., 10(1), 43-45.

Deveci, E.; Söker, S.; Baran, Ö. (2011). Ultra structural changes in the kidney cortex of rats treated with lead acetate. Int. J. Morphol., 29(3), 1058-1061.

Favareto, A.P.A.; Fernandez, C.D.B.; Fossato, D.; Silva, D.A. (2011). Persistent Impairment of Testicular Histology and Sperm Motility in Adult Rats Treated with Cisplatin at PeriPuberty. Bas. and Clin. Pharmacol. and Toxicol., 109, 85-96.

Finkel, T. (2003). Oxidant signals and oxidative stress. Curr.Opin. Cell Biol. , 15(2), 247-254.

Guidet, B.; Shah, S.V. (1989). Antioxidant assay. Am. J. Physiol., 257(26), 440.

Han, M.S.; Chung, K.W.; Cheon, H.G. (2009). Imatinib mesylate reduces endoplasmic reticulum stress and induces remission of diabetes in db/db mice. Diabetes, 58(2), 329-336.

Hassan, N.A.M.; Yousef, M.M. (2013). Study of imatinib cardiotoxicity in adult male rabbits. $J$. Environmental Science. Toxicol. and Food Technology (IOSR-JESTFT), 6(5), 14-26.

Herman, E.H.; Knapton, A.; Rosen, E. (2011). A multifaceted evaluation of imatinib-induced cardiotoxicity in the rat. Toxicol. Pathol., 39(7), 1091-1106.

Howell, S.J.; Shalet, S.M. (2005). Spermatogenesis after cancer treatment: damage and recovery. $J$ Natl. Cancer Inst. Monogr., 34, 12-17.

Hu, W.; Lu, S.; McAlpine, I. (2012). Mechanistic investigation of imatinib-induced cardiac toxicity and the involvement of c-abl kinase. Toxicol. Sci., 129(1), 188-199.

Ilbey, Y.O.; Ozbek, E.; Cekmen, M. (2009). Protective effect of curcumin in cisplatin-induced oxidative injury in rat testis: mitogen-activated protein kinase and nuclear factor-kappa B signaling pathways. Hum. Repro., 24(7),1717-1725.

Kerkela“, R.; Grazette, L.; Yacobi, R. (2006). Cardiotoxicity of the cancer therapeutic agent imatinib mesylate. Nat. Med., 12(8), 908-916.

Kim, H.; Chang, H.M.; Ryu, M.H. (2005). Concurrent male gynecomastia and testicular hydrocele after imatinib mesylate treatment of a gastrointestinal stromal tumor. J. Korean. Med. Sci., 20(3), 512-515. 
Kim, R.; Tanabe, K.; Uchida, Y. (2002). Current status of the molecular mechanisms of anticancer drug-induced apoptosis. The contribution of molecular-level analysis to cancer chemotherapy. Cancer Chemother. Pharmacol., 50, 343-352.

Kose, E.; Sapmaz, H.I.; Sarihan, E. (2012). Beneficial Effects of Montelukast Against Methotrexate-Induced Liver Toxicity: A Biochemical and Histological Study. Sci. World J., 987508.

Łubgan, D.; Marczak, A.; Walczak, M. (2006). Pharmacological mechanisms of Doxorubicin activity (DOX) - current state of knowledge. Przegl. Lek., 63,782-788.

Marcolino, M.S.; Boersma, E.; Clementino, N.C.D. (2011). Imatinib treatment duration is related to decreased estimated glomerular filtration rate in chronic myeloid leukemia patients. Annals. Oncology. , doi: 10.1093/annonc/mdq 715 |1-7.

Mohan, M.; Bhandare, S. (2012). Protective effect of solanum torvum against testicular toxicity in male wistar rats. Int. J. Pharm. Pharm. Sci., 4(3), 188-192.

Murawska-Ciałowicz, E.; Bal, W.; Januszewska, L. (2012). Oxidative stress level in the testes of mice and rats during Nickel intoxication. Sci. World J. Article ID 395741, 5 pages, doi: $10.1100 / 2012 / 395741$.

Nurmio, M.; Toppari, J.; Zaman, F. (2007). Inhibition of tyrosine kinases PDGFR and C-Kit by imatinib mesylate interferes with postnatal testicular development in the rat. Int. $J$. Androl., 30, 366-376.

Padmini, M.P.; Kumar, J.V. (2013). An experimental study of biochemical and histopathological study on gentamycin induced renal failure in albino rat and the effectiveness of punarnava (boerhaevia diffusa) on reversal of renal damage. IOSR-JDMS, 9(6), 17-21.

Prasad, A.M.; Ramnarayan, K.; Bairy, K.L. (2010). Effect of imatinib on histological parameters in albino mice. J. Pharmaceutical Sci. Rev. and Res., 4(2), 117-122.

Ramos, S.D.P.; Goessler, K.F.; Ruiz, R.J. (2013). Exercise protects rat testis from cyclophosphamide-induced damage. Acta Scientiarum. Biol. Sci. Maringá, 35(1), 105-113.

Ribeiro, A.L.; Marcolino, M.S.; Bittencourt, H.N. (2008). An evaluation of the cardiotoxicity of imatinib mesylate. Leuk. Res. 32(12), 1809-1814.

Saad, S.Y.; Alkharfy, K.M.; Arafah, M.M. (2006). Cardiotoxic effects of arsenic trioxide/ imatinib mesilate combination in rats. JPP., 58, 1-7.

Sawyers, C.L. (2003). Opportunities and challenges in the development of kinase inhibitor therapy for cancer. Genes and Dev, 17, 2998-3010.

Sedlak, J.; Lindsay, R.H. (1968). Estimation of total, protein-bound, and nonprotein sulfhydryl groups in tissue with Ellman's reagent. Anal. Biochem., 24,25(1), 192-205.

Shah, R.R.; Morganroth, J.; Shah, D.R. (2013). Hepatotoxicity of tyrosine kinase inhibitors: clinical and regulatory perspectives. Drug Saf., 36(7), 491-503.

Shaker, M.E.; Shiha, G.E., Ibrahim, T.M. (2011). Comparison of early treatment with low doses of nilotinib, imatinib and a clinically relevant dose of silymarin in thioacetamide-induced liver fibrosis. Euro. J. Pharmacol., 670(2-3), 593-600.

Thanopoulou, E.; Judson, I. (2012). The safety profile of imatinib in CML and GIST: long-term considerations. Arch. Toxicol., 86,1-12.

Vickers, A.E.; Rose, K.; Fisher, R. (2004). Kidney slices of human and rat to characterize Cisplatininduced injury on cellular pathways and morphology. Toxicol. Pathol., 32, 577-590.

Wolf, A.; Couttet, P.; Dong, M. (2010). Imatinib does not induce cardiotoxicity at clinically relevant concentrations in preclinical studies. Leuk. Res., 34(9), 1180-1188.

Yaghmaei, P.; Parivar, K.; Gharibi, A. (2009). The biological effects of imatinib on male fertility of wistar rats. IJFS, 3(3), 135-142. 